Research article

\title{
CHROMOSOME ABERRATIONS PRODUCED BY MESTRANOL IN HUMAN LYMPHOCYTE CULTURES
}

\author{
TEODOROVIĆ Radislava ${ }^{1}$, DRAŠKOVIĆ Vladimir ${ }^{1}$, ĐURIĆ Spomenka ${ }^{2}$, \\ NENADOVIĆ Kartarina ${ }^{1 *}$, MIRILOVIĆ Milorad ${ }^{2}$, JANKOVIĆ Ljiljana ${ }^{1}$ \\ ${ }^{1}$ Department of Animal Hygiene, Faculty of Veterinary Medicine, University of Belgrade, Bul. \\ Oslobođenja 18 Belgrade, Serbia; ${ }^{2}$ Department of Economics and Statistics, Faculty of Veterinary \\ Medicine, University of Belgrade, Bul. Oslobođenja 18 Belgrade, Serbia
}

(Received 10 July, Accepted 29 October 2019)

In this investigation, the genotoxic properties of mestranol were examined in vitro. Human lymphocyte cultures were exposed for $72 \mathrm{~h}$ to mestranol at concentrations of $7.5,15$ and $30 \mu \mathrm{g} / \mathrm{g}$. The genotoxic effects of the chemosterilant were assessed by numerical and structural chromosome aberrations.

Mestranol induced certain genotoxic effects in human lymphocytes. There was a dose-dependent significant $(\mathrm{p}<0.01)$ increase in the number of numerical aberrations in comparison to the control, but without significant differences $(p>0.05)$ between the doses applied. Further, structural aberrations increased significantly $(\mathrm{p}<0.01)$ in the presence of mestranol, being most frequent in cultures exposed to the highest mestranol dose.

The frequency of Robertsonian translocations increased significantly only in cultures treated with mestranol at concentration of $30 \mu \mathrm{g} / \mathrm{g}$ in comparison both with the control $(p<0.01)$ and the lowest chemosterilant dose $(p<0.01)$.

There were significant differences $(\mathrm{p}<0.01)$ in the levels of chromosome gaps and fragments compared to Robertsonian translocations, whilst the frequencies between gaps and fragments were not significantly different $(p>0.05)$.

Keywords: mestranol, cytogenetics, genotoxicity, human lymphocytes

\section{INTRODUCTION}

The number of mouse-like rodent populations has been growing continuously during evolution and accordingly and caused damages inflicted to humans directly or indirectly. Owing to the obvious economic and epidemiological/epizootiological importance of rodents, it is necessary to carry out a systematic rodent control, which means to

\footnotetext{
*Corresponding author: e-mail: katarinar@vet.bg.ac.rs
} 
reduce the populations of harmful rodents to tolerable levels, all of which is aimed at preserving the health of people, domestic animals and game, as well as tangible assets. The use of mechanical, physical, biological and chemical means of combat against mouse-like rodents has not lead to satisfactory results, that is, satisfactory results can be achieved in small buildings or in larger on condition they are not heavily invaded.

Given the growing emergence of resistance of rodents to rodenticides, [1] there is a necessity to produce novel methods, or novel chemical compounds in order to fight and regulate the populations of mouse-like rodents. One of the products, available on the market, are ready-to-use baits based on chemosterilants (mestranol). The mode of action of chemosterilants is based on their ability to lead to temporary or permanent sterility of males or females only, or both genders of harmful rodents. They may directly or indirectly impair the development or maturation of gametes prior to or after copulation, prevent the fusion of the egg cell and the sperm cell and, finally, the implantation of the fertilized ovum in the uterus [2]. Further, they can suppress the sexual development of the offspring and cause irreversible infertility, cause death in the offspring due to the decrease in maternal lactation [3].

Given that it has been confirmed that some pesticides [4,5] especially rodenticides, mainly based on coumarin and indandione, [6-11] may cause cytological and mitotic changes, and chromosomal aberrations, and that there are scarce data on the genotoxic effects of chemosterilants, it has been decided that in this work we focus on the possible genotoxic effects of mestranol on human lymphocytes in vitro.

\section{MATERIAL AND METHODS}

The genotoxic effects of mestranol (17- $\alpha$-ethynylestradiole-3-methyl ether), a powerful chemosterilant, were assessed in vitro.

Mestranol is a steroid chaemosterilant. Its effects include the inhibition of ovulation, prevention and disruption of implantation, the absorption of the embryo, miscarriage and disrupted sexual development of the offspring. It leads to temporary sterility in mouse-like rodents when used in the dose of $(30-50 \mu \mathrm{g} / \mathrm{g})$ when ingested at the age of 28-days.

\section{Human lymphocyte culture}

Human lymphocyte cells were cultured according to Evans and O'Riordan [13]. Blood samples $(5-10 \mathrm{ml})$ are normally taken from a female donor, 20-25 years old, by venipuncture using a $10-20 \mathrm{ml}$ sterile syringe. The blood is then immediately transferred to a suitable sized sterile tube containing lithium heparin at concentrations of $100 \mathrm{IU} / \mathrm{ml}$ of blood. The cultures were seeded immediately after the blood was taken in sterile $20 \mathrm{ml}$ vials. 
Cells were cultured in Parker 199 medium supplemented with fetal calf serum. In 30$\mathrm{ml}$ sterile vials $0.8 \mathrm{ml}$ of whole blood is added to $10 \mathrm{ml}$ of culture medium.

The $\mathrm{pH}$ of the nutrient medium was maintained at 6.8-7.2 by addition of bicarbonate buffer. To minimize the risk of culture contamination, $100 \mathrm{IU} / \mathrm{ml}$ Penicillin and Streptomycin were added to the medium.

Phytohemagglutinin-PHA was used to initiate lymphocytes mitotic divisions, otherwise stopped in the Go phase. Immediately after the addition of PHA, $7.5 \mu \mathrm{g} / \mathrm{g}, 15 \mu \mathrm{g} / \mathrm{g}$ and $30 \mu \mathrm{g} / \mathrm{g}$ of mestranol were added to the cultures.

The culture vials were placed in the incubator at $37^{\circ} \mathrm{C}$ for $72 \mathrm{~h}$. During the last $3 \mathrm{~h}$ prior to harvesting the cells, a spindle inhibitor colchicine (Merck) was added to the culture at a volume that provided a final concentration of $0.5 \mathrm{mg} / \mathrm{ml}$ to block the spindle, providing sufficient metaphase cells for chromosomal analysis.

Chromosome analyses were performed in cells marked in Carman solution and diluted in $0.56 \% \mathrm{KCl}$. [12].

To study the genotoxicity of mestranol, human lymphocytes were exposed to 7.5, 15 and $30 \mu \mathrm{g} / \mathrm{g}$ of mestranol in the cell culture for three days. The mitotic activity of the lymphocytes and the occurrence of numerical and structural aberrations were assessed.

\section{Statistical analysis}

The results obtained were analyzed with Student's t-test (Statgraphics 5.0-Statistical Graphics Corporation, USA Programme).

\section{RESULTS}

The results obtained in the research into the influence of mestranol in concentrations of $7.5,15$ and $30 \mu \mathrm{g} / \mathrm{g}$ of culture on the occurrence of numerical chromosome aberrations in human lymphocytes in vitro Table 1 . In a three-day treatment three experimental and a control group of cells were examined. In each experimental group 96-100 metaphase figures were analysed, and 62 were selected from the control.

Table 1. Numerical chromosome aberrations in human lymphocytes induced by mestranol

\begin{tabular}{|c|c|c|c|c|c|c|c|c|c|c|c|}
\hline \multirow{2}{*}{ Doses } & & \multicolumn{6}{|c|}{ Numbers of chromosomes } & \multicolumn{2}{|c|}{ Aneuploidy } & \multicolumn{2}{|c|}{ Polyploidy } \\
\hline & & $<46$ & $\%$ & 46 & $\%$ & $>46$ & $\%$ & No. & $\%$ & No. & $\%$ \\
\hline K & 62 & 1 & 1.61 & 61 & 98.38 & 0 & 0.00 & 1 & 1.61 & 0 & 0.00 \\
\hline I & 100 & 8 & 8.00 & 89 & 89.00 & 3 & 3.00 & 11 & 11.00 & 0 & 0.00 \\
\hline II & 96 & 7 & 7.92 & 86 & 89.58 & 3 & 3.12 & 10 & 10.41 & 0 & 0.00 \\
\hline III & 77 & 7 & 9.09 & 67 & 87.01 & 2 & 2.59 & 9 & 11.68 & 1 & 1.29 \\
\hline
\end{tabular}

Tested conc.: $\mathrm{K}-$ control group, I - $7.5 \mu \mathrm{g} / \mathrm{g}, \mathrm{II}-15 \mu \mathrm{g} / \mathrm{g}$, III $-30 \mu \mathrm{g} / \mathrm{g}$ 
In the solvent control, a diploid number of chromosomes was detected in $98.38 \%$ of the cells analyzed and aneuploidy was found in 1.61\%, polyploidy did not occur. In mestranol-treated cultures the percentage of lymphocytes with aneuploidy was dosedependent: in lymphocytes treated with the maximum dose it reached $11.68 \%$, out of which the majority $-9.09 \%$ of the total number of examined - were with haploid metaphases. Along with the increase in the mestranol dose - in 15 and $30 \mu \mathrm{g} / \mathrm{g}-$ there was an increase in the number of polyploid cells from $0.0 \%$ to $1.29 \%$. This increase in the effect of mestranol was statistically significant $(\mathrm{p}<0.01)$. The frequency of numerical aberrations in all of the three mestranol doses was significantly higher in comparison to the control $(\mathrm{p}<0.01)$, with the exception of polyploidy, which did not increase significantly $(\mathrm{p}>0.05)$.

The second part of the research consisted of the assessment of structural chromosome aberrations in human lymphocyte cultures exposed to various doses $(7.5,15$ and 30 $\mu \mathrm{g} / \mathrm{g}$ culture medium) of mestranol for $72 \mathrm{~h}$. The average values of chromosomal damages are shown in Table 2.

Table 2. Cytogenetic damage and Robertsonian translocations in cultured human lymphocytes caused by mestranol

\begin{tabular}{cccc}
\hline \multirow{2}{*}{ Groups } & \multicolumn{3}{c}{ Structural chromosomal abnormalities \% } \\
\cline { 2 - 4 } & Gaps & Fragments & Robertsonian translocations \\
\hline K & 0.0 & 1.0 & 0.0 \\
I & 4.0 & 5.5 & 0.0 \\
II & 10.5 & 10.0 & 1.0 \\
III & 11.0 & 11.0 & 2.0 \\
\hline
\end{tabular}

Tested conc.: K - control group, I - $7.5 \mu \mathrm{g} / \mathrm{g}$, II - $15 \mu \mathrm{g} / \mathrm{g}$, III - $30 \mu \mathrm{g} / \mathrm{g}$

Table 3. shows the results of chromosome aberrations produced by mestranol in human lymphocyte cultures. The study was performed on a control and three experimental groups of human lymphocytes who were exposed to 7.5, 15 and $30 \mu \mathrm{g} / \mathrm{g}$ of mestranol for three days. In each group 700-800 cell cultures were analyzed.

Table 3. Mitotic activity in cultured human lymphocytes treated with three doses of mestranol

\begin{tabular}{cccccc}
\hline Doses & Viewed mitosis & Mitotic activity & $\mathbf{X}$ & Min-max & $\begin{array}{c}\text { Mean deviation } \\
\text { (SD) }\end{array}$ \\
\hline K & 700 & $6,6,7,6,5,4,6$ & 5,71 & $4-7$ & 0.9512 \\
I & 700 & $4,4,5,4,5,6,4$ & 4,57 & $4-6$ & 0.7868 \\
II & 800 & $3,4,4,4,3,3,4,3$ & 3,50 & $3-4$ & 0.5345 \\
III & 700 & $2,3,3,3,2,2,3$ & 2,57 & $2-3$ & 0.5345 \\
\hline
\end{tabular}

Tested conc.: $\mathrm{K}$ - control group, I - $7.5 \mu \mathrm{g} /$ sample, II - $15 \mu \mathrm{g} /$ sample III - $30 \mu \mathrm{g} / \mathrm{sample}$ 
The control experimental group showed an average mitotic activity of 5.71 with more distinct individual variability, ranging from 4-7. During the treatment of human lymphocytes, the mitotic activity decreased depending on the dose. The lowest mitotic activity of 2.57 was registered in the group which was exposed to $30 \mu \mathrm{g} / \mathrm{g}$ of mestranol. A low individual variability was present in all experimental groups.

\section{DISCUSSION}

The research was done on three experimental groups and one control group of cultures. In all the groups on average 100 metaphase figures have been analysed. In the control group chromosomal gaps and fragments occurred sporadically $(1 \%)$. Robertsonian translocations have not been noticed. With the increase in the dose, at the same length of exposition, the frequency of structural aberrations increased and reached its maximum at the highest dose of mestranol $(30 \mu \mathrm{g} / \mathrm{g}$ of culture medium). The increase was dose-dependent and significant $(p<0.01)$, with the exception of Robertsonian translocations, which were increased significantly only in cultures treated with the highest dose of mestranol $(30 \mu \mathrm{g} / \mathrm{g}$ culture medium). Statistically significant $(\mathrm{p}<0.01)$ differences were noticed between doses $30 \mu \mathrm{g} / \mathrm{g}$ and $7.5 \mu \mathrm{g} / \mathrm{g}$. Also, statistically significant differences between the levels of gaps and fragments, in comparison to Robertsonian translocations $(\mathrm{p}<0.01)$ were recorded, while the numbers of gaps and fragments were not significantly different.

In addition to this, the statistically significant differences in the levels of gaps and fragments are comparable to Robertsonian translocations $(\mathrm{p}<0.01)$, whilst the number of chromosome breaks did not change significantly.

Based on the results of this research it is obvious that mestranol in the doses administered may do damage to the genetic material in human lymphocyte cultures exposed for 72 h. Cytogenetic changes were recorded also due to some other rodenticides, [14-16] as well as in a number of other substances in use in veterinary medicine [17-20]. The majority of those researches were performed in vitro, in human lymphocyte cultures, $[21,22]$ similarly to our study. Besides genotoxic effects, as a final consequence to the genetic material, which have been detected in our research on mestranol, [23-25] this substance leads to infertility predominantly in male rodents, to temporary infertility in monkeys, but does not affect fertility in mice and hares.

\section{CONCLUSIONS}

In human peripheral blood lymphocyte cultures exposed for $72 \mathrm{~h}$ to various doses of mestranol -7.5, 15 and $30 \mu \mathrm{g} / \mathrm{g}$ medium, a mitotic suppression activity was noticed when compared to the negative control. 
Mestranol in various doses $-7.5,15$ and $30 \mu \mathrm{g} / \mathrm{g}$, in a three-day treatment expressed a mitotic suppression activity in lymphocyte cells of peripheral blood in vitro, in comparison to the control group.

The tested chemosterilant proved capable of producing numerical and structural chromosomal aberrations in human lymphocytes in vitro.

\section{Authors' contributions}

TR coordinated the study, elaborated the experimental design, conducted the experiments and wrote the paper with input from all authors. DV, NN and JLj conducted the experiments and reviewed the manuscript. ĐS and MM analysed the data and reviewed the manuscript. All authors read and approved the final version of the manuscript.

\section{Declaration of conflicting interests}

The author(s) declared no potential conflicts of interest with respect to the research, authorship, and/or publication of this article.

\section{REFERENCES}

1. Stanimirović Z, Vučinić M, Soldatović B, Marković B: Genotoxicity and potential hemosterilant effects of Rodol, Acta Vet Beograd 1997, 47: 237-246.

2. Shoupe D: The Handbook of Contraception. A Guide for Practical Management. Springer Science \& Business Media.. EE is about 1.7 times as potent as the same weight of mestranol. 2007, 23-ISBN978-1-59745-150-5.

3. Gao Y., Short R. V: The control of rodent populations, Oxford Reviews Of Reproductive Biology 1993, 15:263-310

4. Hiromichi O, Maki I, Yosuke M, Taishi T, Motoshi T: Dffect of Pasteurella multocida soluble antigen stimulation on the in vitro response of peripheral blood mononuclear cells of holstein calves. Acta Vet-Beograd 2018, 68(2): 201-210.

5. Stanimirović Z, Vučinić M, Soldatović B, Marković B: Genotoxicity and potential hemosterilant effects of Rodol, Acta Vet Beograd 1997, 47: 237-246.

6. Kataranovski D: Citotoksični efekat antikoagulantni rodenticida na populacije vrste Rattus norvegicus BERK 1769 i čoveka, Magistarski rad, Centar za multidisciplinarne studije Univerziteta u Beogrdau 1985.

7. Sofradžija A., Hadžiselimović R, Maslić E,: Genotoksičnost pesticida, Svjetlost Sarajevo. 1989.

8. Soldatović B, Janković D, Milosavljević S, Savić I, Kataranovski D: Dejstvo Rakumina 57 i Rosola na hormone sivog pacova, VIII Simpozijum iz oblasti DDD, Ohrid, 1979, 4-6.

9. Soldatović B, Zimonjić D, Kataranovski D, Savić I:, Citogenetički efekti Rakumina 57 i DDT-a na ćelije pacova Rattus norvegicus i čoveka, Zbornik radova II Simpozijuma-DDD u zaštiti zdravlja ljudi, Beograd 1980, 165-168. 
10. Hijová E, Bertková I, Štofilová J, Strojný L, Chmelárová A, Bomba A: Anti-inflammatory potential of Lactobacillus plantarum LS/07 in acute colitis in rats, Acta Vet-Beograd 2018, 68(1):55-64.

11. Vučinić M: Uticaj kombinovane intragastrične aplikacije benzalkonijum-hlorida i varfarinnatrijuma na citogenetičke promene ćelija kostne srži i semenika laboratorijskih miševa, Doktorska disertacija, Beograd 1994.

12. Hsu TC, Patton JI: Bone marow preparations for chromosome studies, In: Bemirschke K (Ed). Comparative mammalian cytogenetics, Springer Verlag, Berlin Heikdelberg New York 1969, 454-460.

13. Falaq N, Jyoti S, Akhtar N, Afzal M, Siddique YH: Genotoxic damage in cultured human peripheral blood lymphocytes of oral contraceptive users. Egypt J Med Hum Genet 2012, 13(3): 301-305.

14. Kataranovski D.S, Kataranovski M.V, Ivanovic, I., Mandic-Radic, S: The toxicity of rodenticides in rats following topical application I LD 50 and LD 100 values and changes of selected serum and urine biochemical parameters. Journal-Serbian Chemical Society 1994, 59:787-787.

15. Faigle, J.W, Schenkel, L: "Pharmacokinetics of estrogens and progestogens". In in Fraser; Ian S. Estrogens and Progestogens in Clinical Practice. London. Churchill Livingstone 1989, 273-294. ISBN0-443-04706-5.

16. Lemke L.T,. Williams A.D: Foye's Principles of Medicinal Chemistry. Baltimore 2007, ISBN0781768799.

17. Teodorović R: Cytogenetic changes in bone marrow and fibroblast cells of BALB/C laboratory mice induced by Mestranol, Acta Vet Beograd 2004, 54:263-270.

18. Falcone T, Hurd W: Clinical Reproductive Medicine and Surgery. Elsevier Health Sciences. 2007, 388-.ISBN0-323-03309-1.

19. Stanimirović Z, Fišter S, Stevanović J: Analysis of sister-chromatid exchanges in cultured human lymphocytes treated with cymiazole hydrochloride, Acta Vet Beograd 2003,53: 419425.

20. Schmider J, Greenblatt D J, Moltke L, Karsov D, Hylar V R L, Friedman R I Shader: Biotransformation of Mestranol to Ethinyl Estradiol In Vitro: The Role of Cytochrome P-450 2C9 and Metabolic Inhibitors. The Journal of Clinical Pharmacology 1997, 37, 3, 193

21. Stanimirović Z, Todorović D, Stevanović J, Mladenović M., Janković Lj, Đorđević M: Influence of cymiazole hydrochloride on mitotic and proliferative activities of cultured human lymphocites, Acta Vet Beograd 2003, 53:47-55.

22. Đelić N, Spremo-Potparević B, Marković B, Živković L, Đelić D: Cell cycle kinetics and cytogenetic change in human lymphocites exposed to ostradiol in vitro, Acta Vet Beograd 2006, 56: 37-48.

23. Filshie M, Guillebaud J: Contraception Science and Practice. Elsevier Science 2013, 12 ISBN978-1-4831-6366-6.

24. Marks L: Sexual Chemistry. A History of the Contraceptive Pill. Yale University Press. 2012, 75-ISBN978-0-300-16791-7.

25. Lentz M G, Lobo A R,Gershenson M D, Vern L K:Comprehensive Gynecology. Elsevier Health Sciences.2012, 224-.ISBN0-323-06986-X. 


\title{
CITOGENETIČKE PROMENE U KULTURI LIMFOCITA INDUKOVANE MESTRANOLOM
}

\author{
TEODOROVIĆ Radislava, DRAŠKOVIĆ Vladimir, ĐURIĆ Spomenka, \\ NENADOVIĆ Kartarina, MIRILOVIĆ Milorad, JANKOVIĆ Ljiljana
}

U ovom radu su izvršena ispitivanja genotoksičnih svojstava mestranola u različitim dozama: 7,5, 15 i $30 \mu \mathrm{g} / \mathrm{g}$ kulture ćelija - humanih limfocita, tokom ekspozicije od 3 dana, u uslovima "in vitro". Procena genotoksičnih efekata mestranola urađena je na osnovu numeričkih i strukturnih aberacija u tri eksperimentalne grupe sa po jednom kontrolnom za svaku dozu. Na osnovu rezultata naših ispitivanja može se zaključiti da mestranol u testiranim dozama dovodi do genotoksičnih efekata na limfocitima čoveka. Broj numeričkih aberacija se povećavao sa rastom doze i statističkom analizom su utvrđene signifikantne razlike $(<0,01)$ u odnosu na kontrolne grupe, ali ne i između primenjenih doza $(>0,05)$. U slučaju poliploidija nije utvrđena statistički značajna razlika u odnosu na kontrolnu grupu $(>0,05)$. Analizirajući dobijene rezultate utvrđeno je da sa povećanjem doze pri istoj ekspoziciji dolazi do statistički značajnog $(<0,01)$ povećanja broja strukturnih aberacija na limfocitima, pri čemu najviši nivo je postignut kod najviše primenjene doze (30 $\mu \mathrm{g} / \mathrm{g}$ c.c.). Kada su u pitanju Robertsonove translokacije statistička značajnost u odnosu na kontrolnu grupu utvrđena je tek kod najviše primenjene doze $(30 \mu \mathrm{g} / \mathrm{g}$ c.c.). Statistički značajne razlike $(\mathrm{p}<0,01)$ su zabeležene između doza od $30 \mu \mathrm{g} / \mathrm{g}$ c.c i 7,5 $\mu \mathrm{g} / \mathrm{g}$ c.c. Takođe statistički značajne razlike između nivoa otvora i fragmenata mogu se uporediti sa Robertsonovim translokacijama $(p<0,01)$, dok se broj otvora fragmenata neće značajno promeniti. 